\section{West Germany cracks down on exports of weapons gas}

Munich

WEST German Chancellor Helmut Kohl withstood a blistering attack for his behaviour in the continuing Libyan chemical weapons scandal as his government introduced new measures on 15 February to tighten West German export laws.

Kohl's centre-right coalition government last week issued a report confirming that Bonn was informed as early as 1980 that West German companies might be participating in the building of a chemical weapons factory at Rabta in Libya. (Kohl's government took office only in 1982.) In 1985, the West German com-

about the charges earlier than October 1988 , then he was remarkably uninformed, said SPD parliamentarians. And if he did know, they asked, why didn't he do anything?

Kohl was criticized by his own coalition partners in the parliamentary debate, raising the spectre of a breach within the six-year-old coalition. Although foreign and West German observers foresee no immediate change of government, there is some speculation that the coalition might not survive the 1990 parliamentary elections.

The government's plan for improving export controls includes lengthening the

Export restrictions on chemicals with 'weapons' applications

\begin{tabular}{lcccc}
\multicolumn{1}{c}{ Compound } & United & United & West & East \\
Gingdom & States & Fermany \\
Germany \\
1. Thiodiglycol
\end{tabular}

: Export licences required. $\Xi$ : Licence required for export to certain countries. $\square$ : Export licences to be required in near future. --: No licence required. Data are courtesy of the Geneva Disarmament Conference. The first five compounds on the list include precursors of mustard gas and the nerve gases tabun and sarin. The list includes fluoridating agents (14) and solvents (15) with a number of industrial and pharmaceutical uses as well as phosphoorganic (6-8) that may serve as nerve gas precursors. (Data supplied by Verband der Chemischen Industrie).

panies involved were first mentioned by name in a confidential report from the West German ambassador in Moscow. The list included Imhausen-Chemie $\mathrm{GmbH}$, the company that allegedly designed the factory and provided West German engineers to help with its construction.

The government now says that it could not have acted sooner to stop exports to Libya. A preliminary investigation was not warranted until July 1988, Chancellery Minister Wolfgang Schäuble insisted last week, adding that Kohl was first informed of the charges on 20 October 1988.

The opposition Social Democrats battered Kohl in an unusually acrimonious televised parliamentary debate. Party leader Hans-Jochen Vogel accused Kohl of "shameful" insensitivity for not acting sooner. If Kohl did not know list of banned chemicals and equipment, improving communications among export authorities in West Germany, increasing the penalties for those involved in chemical or biological arms production, and increasing threefold the personnel responsible for monitoring West Germany's massive exports. The plan was agreed upon in principle by all parties. Legislation is expected to follow later this year.

West German Foreign Minister HansDietrich Genscher (Free Democrat) acknowledged that unilateral action to ban chemical arms exports is insufficient. He called for rapid progress towards an international, verifiable ban on the manufacture of chemical weapons and on stockpiling.

In a late development on 20 February, foreign ministers of all 12 members of the European Community (EC) voted to require export licences for 8 chemical

\section{Soviet research ship is impounded for "illegal entry"}

\section{London}

THE Soviet research ship Akademik Mstislav Keldysh became the focus of a diplomatic incident two weeks ago, when the harbour authorities at Freetown, Sierra Leone, impounded the ship for allegedly making an illegal entry into the harbour.

The nuclear-powered ship, which belongs to the Soviet Academy of Sciences, carries two submarines for sea-bed exploration and a scientific staff of $\mathbf{1 0 0}$. According to the Soviet Foreign Ministry, the ship entered Freetown to replenish its stocks of water and to pick up British and West German scientists who were to join the research team. The 72-hour notice of entry required by the Sierra Leonese authorities was duly given, the foreign ministry said.

Why the Sierra Leonese impounded the ship is not clear. According to the Sierra Leonese High Commission in London, there was some suspicion that there were marines on board. This may explain the assertion, in the Soviet protest note, that "a strictly scientific vessel is being made out to be almost a military ship that had entered the territorial waters of Sierra Leone illegally". The attitude of the Freetown authorities, the note said, "gives reason for believing that this is a case of deliberate provocation", and the Soviets cautioned Sierra Leone that it should "seriously weigh up all the possible consequences to which its unfriendly steps with regard to the USSR could lead."

The Akademik Mstislav Keldysh was eventually released and has resumed research operations. Vera Rich

compounds (1-8 in the table), and to forbid export of these substances into "war zones', although it will be some time before these new requirements will come into effect.

The dual-purpose nature of many chemical weapon-precursors makes international monitoring difficult. Controls were reportedly considered for isopropyl alcohol because it is a key ingredient in the mixing of binary chemical weapons. The new West German export regulations foresee mandatory licensing for the export of compounds 9 to 17 (see below), as is US practice for exports to Libya, Syria, Iran and Iraq.

The West German chemical industry organization Verband der Chemischen Industrie agreed last week to voluntary registration of exports of 23 additional compounds. The new regulations will for the first time require licences for export to 'sensitive areas' such as the Middle East.
Steven Dickman 